Article

\title{
Go Forth and Multiply: Revisiting Religion and Fertility in the United States, 1984-2008 ${ }^{\dagger}$
}

\section{Casey Borch ${ }^{1}{ }^{*}$, Matthew West ${ }^{1}$ and Gordon Gauchat ${ }^{2}$}

1 Department of Sociology, University of Alabama at Birmingham, 1401 University Blvd, HHB 460D, Birmingham AL, 35294-1152, USA; E-Mail: mawest@uab.edu

2 Cecil G. Sheps Center for Health Services Research, University of North Carolina, 725 Martin Luther King, Jr. Blvd., Chapel Hill, NC 27599-7590, USA; E-Mail: ggauchat@ schsr.unc.edu

$\dagger$ An earlier version of this paper was presented at the 2008 Annual Meetings of the Eastern Sociological Society, New York.

* Author to whom correspondence should be addressed; E-Mail: caborch@ uab.edu; Tel.: +1-205-934-3943; Fax: +1-509-461-7017.

Received: 1 June 2011; in revised form: 30 August 2011 / Accepted: 5 September 2011 / Published: 27 September 2011

\begin{abstract}
Many studies on the fertility differential by religion have considered both Catholics and Protestants to be equally homogenous groups. Contrary to these studies, we contend that Protestant fertility must be studied in the context of heterogeneous groups. Specifically, conservative Protestantism, with its beliefs about artificial birth control mirroring Catholic teaching, should be examined separately from other Protestant traditions. Using data from the General Social Survey we find that conservative Protestants and Catholics had about the same level of fertility, while mainline Protestants have a fertility rate that is significantly lower than that of Catholics. We also examine the changes in these differences over time.
\end{abstract}

Keywords: religion; fertility; Protestant; conservative Protestant; Catholic; trend analyses 


\section{Introduction}

Membership in a religious tradition or denomination can affect fertility [1,2]. Historically, much research has aimed to describe the intersection of religion and fertility in the United States [3-7]. This research has focused on the differential fertility of Protestants and Catholics, but has largely ignored the difference between Protestant sub-groups. In particular, there has been very little research looking at the effect of being a conservative Protestant on fertility compared with other religious groups. Following the work of Woodberry and Smith [8], we use the term "conservative Protestant" in place of Steensland et al.'s [9] "evangelical Protestant." Since "conservative" Protestant includes evangelicals as well as fundamentalists and Pentecostals, it is a more inclusive categorization of the Protestant sub-groups of interest to us.

Conservative Protestantism represents the largest religious tradition in the United States, which corresponds to roughly $30 \%$ of the U.S. population [8,10]. Hout and Fischer [11] found that conservative Christians tend to have higher fertility than non-conservatives, and thus predicted a growth of conservative religious traditions over time, which includes conservative Protestants. One prominent study looking at the fertility differences between U.S. Protestants concluded that evangelical Protestants will be the next promising arena for the study of American fertility behavior ([6], p. 542):

Recent surveys have found an increase in religious interest in the United States, probably due in part to the so-called evangelical movement. Yet almost nothing is known about the fertility consequences of this phenomenon. As Catholic and Protestant fertility levels continue to converge (Westoff and Jones), this and other dimensions of Protestant life seem promising choices as new arenas for the study of American fertility behavior.

The primary purpose of this study is to examine the association between conservatism and fertility in the United States. Are the higher levels of fertility found among conservative Protestants due to intrinsic components of their religious tradition, or are they a statistical artifact created by an underlying demographic structure? That is, does religious affiliation explain their high levels of fertility, or does the characteristic hypothesis-which asserts underlying demographic characteristics are the primary predictors of fertility_provide more accurate predictors of their fertility?

By examining this association, we will add to the literature in two important ways. First, currently there is little research applying multivariate models to explain the relationship between conservative Protestants and fertility behavior. This study hopes to re-open research on religion and fertility in the U.S. specifically focusing on conservative Protestants. Second, this study will explore future fertility trends of conservative Protestants, which will have implications relating to the future of the U.S. religious and political landscape. Future fertility trends are important because of conservatives' influence as a religious and political movement, and their growth may affect their efficacy as a social movement [12].

\section{Background}

Religious affiliation and fertility were formerly at the forefront of demographic research in the United States. Pearce [13] posits that, given the many studies demonstrating that the number of 
children in a family varies from religion to religion, it is reasonable to assume that there is a connection between religion and fertility. Most research in this tradition emphasizes the discrepant fertility patterns between Catholics and Protestants [14,15]. These studies, along with those focusing on the Jewish population (e.g., [16]), found Catholicism to be more highly correlated with high fertility rates compared to Protestants, Jews, and the non-religious. One of the strongest suggested reasons for high fertility among Catholics was the Church's teaching on contraception and abortion, which strongly prohibited artificial birth control (excluding the rhythm method). Westoff and Jones [7] found that Catholic and non-Catholic fertility rates in America were slowly converging until the baby boom occurred. During the 1950s and early 1960s, Catholic fertility skyrocketed compared to other religions, significantly widening the gap not previously seen in the $19^{\text {th }}$ century. By the time Vatican II occurred and the papal encyclical on birth control became public, about one-third of American Catholic women were on the birth control pill [14]. Lenski [17], among others (e.g., [18]), found that the extent to which church members are willing to reform their birth control practices changed the way Catholic leaders thought about "authority" and "dissent." It is at this time when the Catholic Church began to intervene in the sexual behaviors of the married faithful. This led parishioners to begin to disobey church teaching on contraception, among other things.

The final outcome of these changes was Catholic fertility rates matching that of other religious denominations. Westoff and Jones ([7], p. 209) pinnacled this phenomenon with a paper entitled "The End of 'Catholic' Fertility," concluding that, although Catholics in the mid $20^{\text {th }}$ century had slightly higher fertility than their non-Catholic counterparts at this time, towards the mid-1970s "the two trends nearly come together," effectively ending a uniquely Catholic fertility rate. With the apparent end of a "Catholic" fertility having thus occurred, interest in religious affiliation and how it affects fertility withered away as discrepancies in fertility levels between religious groups approached zero.

Along these lines, work by Bartkowski, Xu, and Levin [19] and more specifically Mahoney et al. [20] suggests that "sanctification theory" helps to explain the convergence. Mahoney ([20], p. 222-223) notes that believers "view family relationships as sacred... Judeo-Christian religions portray the burdens and pleasures of parenting as opportunities to model and deepen one's understanding of God's love, patience, and commitment, and frame the parental role as a sacred calling that requires personal sacrifices." Both the Catholic and conservative Protestant faiths have strong emphases on child-rearing as a vocation, responsibility, and calling from God to do their duty and treat children as a gift. By having more children, then, it may be perceived that a couple is being a "good Christian." This is particularly true for conservative Protestants because of their strong belief in the Bible as the literal word of God and the various Biblical commands to "multiply," populate the earth, and the like (as well as God's anger at those who attempt birth control, such as Onan's withdrawal). Thus, more conservative denominations likely place more emphasis on the Bible and its pronatalist worldview. Scripture, along with $\sin$ and salvation, constitute Bartkowski's "three S's" that differentiate conservative Protestants from all others [21]. The authors note that while sanctification of the family may be good in that it promotes social cohesion, it can also prove negative in situations such as the family whose parents are of differing religions.

Past research comparing Protestant and Catholic fertility tended to lump all Protestants together much in the same way as Catholics are lumped together - that is, as one unitary Protestant Church similar to the one Catholic Church — and thus did not pick up the higher levels of fertility occurring for 
conservative Protestants [3,4,7]. This collapsing of Protestant denominations into one conceptual group risks the validity of studies comparing fertility rates by religion. For example, Bean et al. ([22], p. 91) lamented how past studies typically classify respondents as "Protestants, Catholics, and Jews; these categories are not homogenous enough to provide a fair test of the relation between religion and fertility" which was particularly problematic with their sample of Utah Mormons. In addition, Pearce ([13], p. 20) notes that "within Protestantism, studies show substantial variation in fertility across affiliations." Possible explanations for such variation include demographic transition theory and the minority status hypothesis (for a comprehensive review, see [13]).

When conservative Protestants are distinguished from the rest of mainline Protestants, their fertility consistently remains higher than that of mainline Protestants and Catholics. Figure 1 shows the average number of reported children for conservatives, mainline Protestants, and Catholics. All three denominations witnessed a drop in the average number of reported children over the last three decades. This result is consistent with prior research that finds all major religious communities in the United States witnessed a drop in the expected family size as the second demographic revolution occurred $[23,24]$. Conservatives have largely maintained a higher average number of reported children since 1984 than Catholics and Mainline Protestants. Indeed, this mirrors Hout and Fischer's [11] work that finds that the vast majority of conservative Christian growth is due to higher fertility and not conversion. As Greeley [25] hypothesized in his monograph Religion in the Year 2000, growth of a particular religion or denomination will most certainly be determined by the number of present-day adherents' children, not by conversion rates. If conservative Protestants have large families with many children, while Mainline Protestants have smaller families, then conservatives should theoretically have the advantage of numbers in the proceeding generation. This is especially true for conservatives who begin parenting at markedly younger ages than mainline denominations, thus allowing more time for family growth early in the life course [26].

\subsection{Who are the Conservative Protestants?}

Conservative Protestantism is flourishing in the United States while liberal Protestant church membership is in decline [27]. The literature tells that conservative Protestantism acquires and maintains members because they demand complete loyalty, unwavering belief, and rigid adherence to a specified way of life [28,29]. Conservative Protestantism is said to have developed in the 1970s as a reaction to the social revolution which occurred in the previous decade. Conservative Protestants believe that the greater personal freedoms in gender roles and sexuality which became prevalent in the previous decade were undermining their core values [30]. Also, Christian Right activism and evangelical growth focused on resistance to moral relativism in the surrounding culture. Indeed, as Emerson and Hartman ([31], p. 127) write: "Without modernization and secularization [of this century] there would be no fundamentalism..." Membership in evangelical groups has risen significantly since the initial push for activism initiated in the 1970s, with conservative Protestants making up more than a "quarter of the American population" in 1998 and varying from many Americans in their unique opinions on "...gender-roles, childrearing styles, [and] political orientation..." ([8], p. 25). Shibley [32] outlines three components for defining contemporary conservative Protestantism: (1) Have had a born-again experience resulting in a personal relationship with Jesus Christ, (2) Accept the full 
authority of the bible in matters of faith and in daily conduct, and (3) Are committed to spreading the gospel by bearing public witness to their faith. These three components provide the common thread for all conservative Protestants.

\subsection{Conservative Protestants and Fertility}

Theory on religious influences on fertility coupled with prior research on conservative Protestants suggests that there are good reasons to believe that the religious beliefs and practices of conservatives influence their fertility. Current theory on religion and fertility states that there are three components that allow religion to influence fertility behavior [1]. First, religions articulate behavioral norms that have linkages to fertility outcomes (e.g., directive on contraception or teachings related to gender roles and family life). Second, religious groups possess the means to communicate its teachings to its members and enforce compliance. Lastly, members with a strong sense of attachment to the religious community will likely adhere with its norms and teachings. By comparing previous literature studying conservative Protestants with the aforementioned theory on fertility and religion, a strong case can be made to infer that conservative Protestantism influences fertility.

The first component is present with contemporary conservative Protestant churches advocating strong prohibitive norms concerning sexuality, gender roles, and family values [8,32]. Also, conservatives look to the Bible for matters of faith and daily conduct, in which there is considerable evidence that the Bible advocates having numerous children. For example, Genesis 1:28 states "Have many children so that your descendants will live all over the earth and bring it under their control." The second component highlights communication and enforcement of general norms. Again previous research has found conservative Protestants largely possess these means as they acquire and maintain members by demanding loyalty, unwavering belief, and rigid adherence to a specified way of life $[28,29]$. The last component requires a strong sense of attachment to the religious community, which conservative Protestants possess as evident by the popularity of their new market oriented places of worship [32]. In addition, evangelicalism is a religious movement created by feelings of alienation from what they view as an increasing secularized world. These feelings of alienation coupled with numerous popular congregations, in which like-minded individuals attend, provide compelling evidence that many conservative Protestants will feel a strong sense of attachment to their religious community. Overall, there is reasonable evidence to suggest that conservative Protestantism will influence fertility.

\section{Data and Methods}

\subsection{Data}

The data come from the General Social Survey (GSS). The GSS is based on a probability sample of the adult civilian population of the United States, stratified by region and metropolitan versus non-metropolitan residence. The GSS continues to use in-person interviews, and sampling techniques and response rates are well documented [33]. A major advantage of the GSS is that most of the questions keep the same wording from year to year, so data can easily be compared longitudinally or pooled across years. As per the suggestions in the GSS technical information, sample weights were not 
used in our analyses. This is because from 1984-2002 the data were taken from a full probability sample of households in the U.S., thus making the GSS self-weighting. Also, as suggested, we did not include data from 1987, because of an over-sample of Blacks. After 2004, weights are necessary only if the data are analyzed within year. Thus, since our focus is longitudinal and we include dummy variables for each year in our models, we do not have to include sample weights in our models.

\subsection{Variables}

The dependent variable is self-reported fertility. The GSS asked respondents the following question [GSS mnemonic $=$ CHILDS]: "How many children have you ever had? Please count all that were born alive at any time (including any you had from a previous marriage)." The response categories ranged from zero to eight or more children. This question was asked in 17 years over the period 1984 to 2008 .

The following independent variables were included in the models. We measured sex as a dummy variable for female. Although the original dataset included white and an "other" category, we measured race as a dummy variable distinguishing black from all other races. Age was measured continuously by the GSS with a range of 18 to 89 years old. To account for expected non-linearity in the effect of age on fertility, we also included age-squared in the models. Education was included as a continuous variable that ranged from 0 to 20 years of schooling. Marital status is a dichotomous variable that distinguished those married were from those unmarried. We treated household income (in real 2000 dollars) as a continuous variable. A dummy variable to distinguish respondents living in the South from those living elsewhere was created and included in the models. The specific delineation of the states into these regions was determined by the way in which the GSS partitioned the states into regional categories (see Davis et al. [33] for further explanation). We also compared those living in rural areas from those living elsewhere (non-rural). As differentiated by Tuch [34,35], rural included the following areas: Not within an SMSA or standard metropolitan statistical area, (within a county) and-a small city (10,000 to 49,999); a town or village $(2,500$ to 9,999$)$; an incorporated area less than 2,500 or an unincorporated area of 1,000 to 2,499; open country within larger civil divisions, e.g., township, division. Finally, we use Steensland et al.'s [9] typology to place GSS respondents into religious groups. These groups are as follows: Catholics, those with no religious affiliation, those claiming religious faiths other than Christian. The Protestant group was further separated into conservative Protestants, Black Protestants, and other Protestants. Table 1 presents descriptive statistics for all the variables discussed above along with means by decade and correlations with time.

\subsection{Analytic Strategy}

Since the dependent variable is a count variable (i.e., number of children), the most appropriate method of analysis is negative binomial or Poisson regression. The model takes the following form: $\log (\mathrm{m})=\mathrm{a}+\mathrm{bx}$, where the dependent variable $(\mathrm{y})$ and the mean of $\mathrm{y}(\mathrm{m})$ are related by the Poisson distribution (error). Unlike ordinary regression, however, the variance of the error term is fixed. In an ordinary regression, the error variance is estimated from the model. With the Poisson distribution, the error variance is equal to $\mathrm{m}$ (the mean). If the Poisson distribution is appropriate, the deviance will have a chi-square distribution with $\mathrm{N}-\mathrm{k}$ degrees of freedom, where $\mathrm{N}$ is the number of cases (not the 
total number of events) and $\mathrm{k}$ is the number of parameters fitted. In effect, Poisson regression is a log-linear model because it uses the log link.

Table 1. Descriptive Statistics for all Variables in the Models, 1984-2008 (N = 36,020).

\begin{tabular}{|c|c|c|c|c|c|c|}
\hline & Range & $\begin{array}{c}1984-08 \\
\mu \text { or } \%\end{array}$ & $\begin{array}{c}1984-89 \\
\mu \text { or } \%\end{array}$ & $\begin{array}{c}1990-99 \\
\mu \text { or } \%\end{array}$ & $\begin{array}{c}2000-08 \\
\mu \text { or } \%\end{array}$ & $\begin{array}{c}\text { Corr. w/ } \\
\text { time }\end{array}$ \\
\hline Number of Children & $0-8$ & $1.87(1.72)$ & 2.01 & 1.84 & 1.84 & $-0.024 *$ \\
\hline Married & $0-1$ & $50.4 \%$ & $53.6 \%$ & $50.1 \%$ & $48.9 \%$ & $-0.047 *$ \\
\hline Female & $0-1$ & $56.1 \%$ & $56.8 \%$ & $56.5 \%$ & $55.2 \%$ & $-0.018 *$ \\
\hline Education & $0-20$ & $13.1(3.07)$ & 12.4 & 13.2 & 13.4 & $0.036^{*}$ \\
\hline Income / 1000 & $0-141$ & $26.8(29.3)$ & 26.7 & 27.4 & 30.5 & $0.121 *$ \\
\hline Black & $0-1$ & $13.9 \%$ & $17.0 \%$ & $13.2 \%$ & $13.8 \%$ & -0.004 \\
\hline Urban residence & $0-1$ & $40.6 \%$ & $45.0 \%$ & $41.7 \%$ & $43.6 \%$ & $-0.077 *$ \\
\hline South & $0-1$ & $36.1 \%$ & $35.7 \%$ & $35.7 \%$ & $37.9 \%$ & $0.021 *$ \\
\hline Pre-New Dealers $(<1909)$ & $0-1$ & $1.8 \%$ & $4.8 \%$ & $1.1 \%$ & $0.3 \%$ & $-0.129 *$ \\
\hline New Dealers (1909-21) & $0-1$ & $7.4 \%$ & $13.8 \%$ & $7.7 \%$ & $2.5 \%$ & $-0.169 *$ \\
\hline WW II generation (1922-29) & $0-1$ & $7.4 \%$ & $10.5 \%$ & $7.7 \%$ & $4.8 \%$ & $-0.089 *$ \\
\hline Cold Warriors (1930-45) & $0-1$ & $18.7 \%$ & $21.9 \%$ & $19.3 \%$ & $16.5 \%$ & $-0.057 *$ \\
\hline Early Boomers (1946-54) & $0-1$ & $17.9 \%$ & $20.2 \%$ & $18.6 \%$ & $15.7 \%$ & $-0.049 *$ \\
\hline Late Boomers (1955-65) & $0-1$ & $24.8 \%$ & $24.7 \%$ & $26.6 \%$ & $22.9 \%$ & $-0.021 *$ \\
\hline Generation X (1966-77) & $0-1$ & $16.7 \%$ & $4.0 \%$ & $18.2 \%$ & $24.1 \%$ & $0.205^{*}$ \\
\hline Generation Y (1978+) & $0-1$ & $5.3 \%$ & ----- & $0.7 \%$ & $13.3 \%$ & $0.265^{*}$ \\
\hline Age & $18-89$ & $45.8(17.3)$ & 45.3 & 45.5 & 46.6 & $0.036^{*}$ \\
\hline Church attendance & $0-8$ & $3.7(2.69)$ & 3.9 & 3.7 & 3.6 & $-0.061 *$ \\
\hline Catholic & $0-1$ & $25.2 \%$ & $25.5 \%$ & $25.1 \%$ & $25.2 \%$ & -0.006 \\
\hline Protestant & $0-1$ & $57.8 \%$ & $62.9 \%$ & $58.3 \%$ & $53.9 \%$ & $-0.075^{*}$ \\
\hline Mainline Protestant & $0-1$ & $22.9 \%$ & $23.7 \%$ & $23.4 \%$ & $21.4 \%$ & $-0.032 *$ \\
\hline Conservative Protestant & $0-1$ & $21.7 \%$ & $22.9 \%$ & $22.7 \%$ & $20.0 \%$ & $-0.036 *$ \\
\hline Black Protestant & $0-1$ & $9.0 \%$ & $12.1 \%$ & $8.5 \%$ & $8.1 \%$ & $-0.029 *$ \\
\hline Other Protestant & $0-1$ & $4.2 \%$ & $4.1 \%$ & $3.7 \%$ & $4.4 \%$ & -0.001 \\
\hline Other religion & $0-1$ & $5.1 \%$ & $4.3 \%$ & $5.6 \%$ & $5.1 \%$ & $0.016^{*}$ \\
\hline No religion & $0-1$ & $11.9 \%$ & $7.3 \%$ & $10.9 \%$ & $15.7 \%$ & $0.111 *$ \\
\hline
\end{tabular}

Note: Standard errors are in parentheses. ${ }^{*} \mathrm{p}<0.05$

The restriction of variance $=$ mean $\left(\sigma^{2}=\mu\right)$ is often hard to satisfy. In fact, our data are what is known as "over-dispersed." This occurs when the variance is greater than the mean $\left(\sigma^{2}>\mu\right)$, see Table 1 . Running a Poisson model on over-dispersed data can produce unreliable results. If the error is uncorrelated with independent variables, the estimates of the parameters will be unbiased and consistent. However, the standard errors will be underestimated. To avoid this pitfall, methodologists suggest that the negative binomial model is the most appropriate method of analyzing count data that are over-dispersed. The coefficients from negative binomial are interpreted the same as those from Poisson regression: $\left(e^{B}-1\right)^{*} 100$, for percent change, and $e^{B}$, for estimated counts. Negative binomial assumes that the systematic part is $\log (m)=a+b x+u$, where $u$ is a random variable with a gamma distribution. The relationship between $\mathrm{m}$ and $\mathrm{y}$ is again given by a Poisson distribution. The combination of these two assumptions gives you a particular distribution, the negative binomial. The 
assumption of a gamma distribution for $\mathrm{u}$ is somewhat arbitrary. Basically, the assumption is made because it gives a reasonably simple and well known distribution when combined with Poisson. In sum, using the negative binomial model will give more efficient estimates when the distribution is over-dispersed.

\section{Results}

\subsection{General Trends}

Figure 1 displays annual change in mean reported fertility by religious group. Fertility is simply the number of children reported by respondents; it ranges from zero children to eight or more children. The ceiling of eight children was set by the GSS; however this does help to alleviate some of the skew in the variable (skewedness $=1.107$; Kurtosis $=1.174$ ). Reported fertility (hereafter, we will use "fertility" in place of "reported fertility") decreases steadily from the mid-1980s to the late 1990s before rebounding after the turn of the century; particularly among Catholics.

Figure 1. Average Reported Number of Children by Year and by Religious Group.

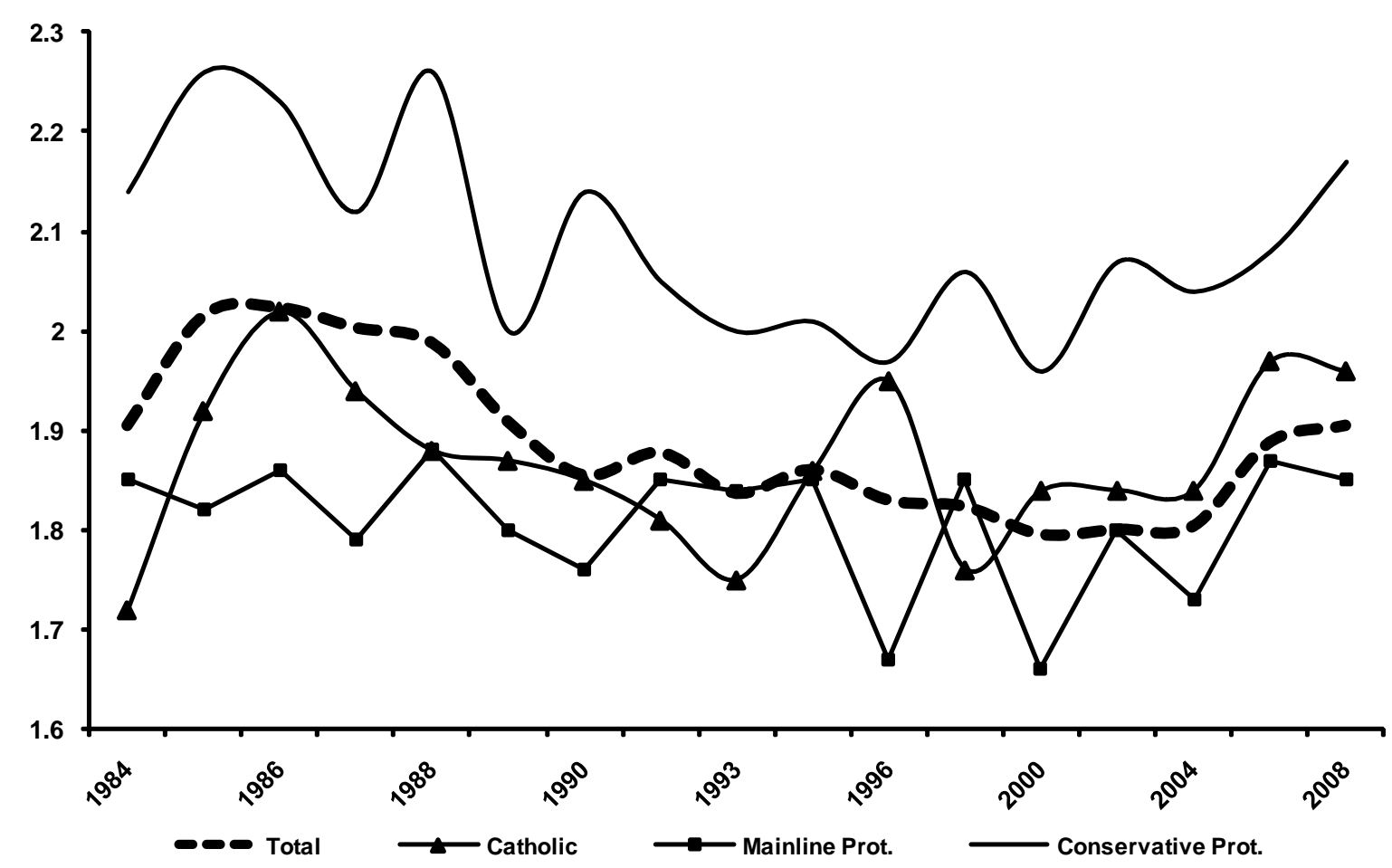

The trends by religious group basically follow the trend of overall fertility (i.e., higher fertility in the early period and lower fertility until late in the period); however, there are two noticeable differences. First, the trend for Catholics is lower than that for Protestants. This realigning of fertility rates by religious group has been documented in other demographic research and thus our results reaffirm that work (e.g., [7]). Secondly, the fertility rates of conservative Protestants are higher than that of both Catholics and other Protestant groups. This trend is especially clear in the early- to mid-stages of our analysis period. In the next section, we explore in more detail these trends. 


\subsection{Regression Models}

Table 2 shows parameter estimates and fit statistics from three different models. The first model includes period effects (dummy variables for each year) and demographic variables with no interactions between them. The estimated effects of the demographic variables are reported in Column 1, while the period effects are omitted to save space.

Table 2. Results of Three Negative Binomial Models Predicting Self-Reported Fertility.

\begin{tabular}{|c|c|c|c|}
\hline$I V$ & $\begin{array}{c}\text { Model 1 } \\
\text { Main Effect }\end{array}$ & $\begin{array}{c}\text { Model } 2 \\
\text { Main Effect }\end{array}$ & $\begin{array}{c}\text { Model } 3 \\
\text { Main Effect }\end{array}$ \\
\hline Intercept & $-1.919 * * *(0.069)$ & $-1.866 * * *(0.069)$ & $-1.881 * * *(0.069)$ \\
\hline \multicolumn{4}{|l|}{ Cohort } \\
\hline Pre-New Dealers (before 1909) & $-0.239 *(0.105)$ & $-0.240 *(0.108)$ & $-0.244 *(0.108)$ \\
\hline New Dealers (1909-21) & $-0.173(0.091)$ & $-0.178(0.091)$ & $-0.183 *(0.091)$ \\
\hline World War II (1922-29) & $0.031(0.230)$ & $0.024(0.081)$ & $0.019(0.081)$ \\
\hline Cold Warriors (1930-45) & $0.151 *(0.069)$ & $0.143 *(0.069)$ & $0.137 *(0.069)$ \\
\hline Early Boomers (1946-54) & $0.150 * *(0.043)$ & $0.143 *(0.057)$ & $0.138 *(0.057)$ \\
\hline Late Boomers (1955-65) & $0.223^{* * *}(0.049)$ & $0.216^{* * *}(0.049)$ & $0.212 * * *(0.049)$ \\
\hline Generation X (1966-77) & $0.272 * * *(0.042)$ & $0.269 * * *(0.042)$ & $0.266 * * *(0.042)$ \\
\hline Generation Y (1978+) & ---- & --- & ---- \\
\hline Age & $0.088^{* * *}(0.003)$ & $0.088 * * *(0.003)$ & $0.088 * * *(0.003)$ \\
\hline Age*Age & $-0.001 * * *(0.000)$ & $-0.001 * * *(0.000)$ & $-0.001 * * *(0.000)$ \\
\hline Married & $0.357 * * *(0.010)$ & $0.356 * * *(0.010)$ & $0.356 * * *(0.010)$ \\
\hline Female & $0.155^{* * *}(0.009)$ & $0.154 * * *(0.009)$ & $0.154 * * *(0.009)$ \\
\hline Education & $-0.056^{* * *}(0.002)$ & $-0.054 * * *(0.002)$ & $-0.053 * * *(0.002)$ \\
\hline Income (divided by 10,000 ) & $-0.003 *(0.001)$ & $-0.004 *(0.002)$ & $-0.003(0.002)$ \\
\hline Black & $0.280 * * *(0.013)$ & $0.292 * * *(0.013)$ & $0.284 * * *(0.019)$ \\
\hline Rural & $0.084 * * *(0.013)$ & $0.087 * * *(0.013)$ & $0.086^{* * * *}(0.013)$ \\
\hline South & $-0.046 * * *(0.010)$ & $-0.040 * * *(0.010)$ & $-0.046 * * *(0.010)$ \\
\hline Religious Service Attendance & $0.020 * * *(0.002)$ & $0.016 * * *(0.002)$ & $0.015 * * *(0.002)$ \\
\hline Protestant & ---- & $-0.058 * * *(0.011)$ & ---- \\
\hline Other Religion & ---- & $-0.170 * * *(0.024)$ & $-0.172 * * *(0.024)$ \\
\hline No Religion & ---- & $-0.139 * * *(0.019)$ & $-0.139 * * *(0.019)$ \\
\hline Catholic & ---- & ---- & ---- \\
\hline Mainline Protestant & ---- & ---- & $-0.097 * * *(0.012)$ \\
\hline Conservative Protestant & ---- & ---- & $-0.014(0.013)$ \\
\hline Black Protestant & ---- & ---- & $-0.039(0.023)$ \\
\hline Other Protestant & ---- & ---- & $-0.035(0.024)$ \\
\hline Deviance & 38624.2 & 38651.6 & 38650.6 \\
\hline LR $\chi^{2}$ ( $\Delta$ from null model $)$ & $3992.5 * * *(35)$ & $3965.1 * * *(38)$ & $3966.1 * * *(41)$ \\
\hline $\mathrm{N}$ & 33,587 & 33,587 & 33,587 \\
\hline
\end{tabular}

Note: $* \mathrm{p}<0.05, * * \mathrm{p}<0.01, * * * \mathrm{p}<0.001$. Standard errors are in parentheses. Dummy variables for each survey Year were omitted to save space. Coefficients were not transformed by exponentiation for presentation. $L R \chi^{2}=$ deviance $_{\text {null }}-$ deviance $_{\text {fitted }}$, with the number of parameters for the significance test in parentheses. 
The results in Column 1 show that married people, females, blacks, and those who live in rural areas, and those who attend religious services regularly all report having more children than their specific counterparts. On the other hand, the more educated, the more affluent, and Southerners report having fewer children than those in the alternative groups. The cohort variable shows the expected pattern of those born in the earlier eras have significantly more children than those from Generation $\mathrm{Y}$ (born after 1978). The effects of age were non-linear. Specifically, the results suggest that additional years of age increase fertility (effect of age $=0.088, \mathrm{p}<0.001$ ) at a decreasing rate (effect of age-squared $=-0.001, \mathrm{p}<0.001)$. Hence, the age effects take on the expected inverted $\mathrm{U}$ shape.

Model 2 adds predictors for religious affiliation to the period effects and demographic predictors found in Model 1. Specifically, we added dummy variables for Protestant, those claiming other religious faiths, and those reporting no religious ties. The reference group is Catholics. The inclusion of the new predictors did not significantly change the direction or significance of the estimates noted in Model 1. The second model addresses the difference in fertility between the two largest religious denominations, Catholic and Protestant. As expected, on average and net of other predictors, Protestants reported significantly fewer children than Catholics. In fact, our models suggest that Protestants have about $\left(\mathrm{e}^{.058}-1\right)^{*} 100=5.6 \%$ fewer children than Catholics. Also, those of other religious faiths and no religion had significantly lower fertility than Catholics-however, these groups have fewer respondents in them.

Model 3 further separates the Protestant denomination into four categories-Mainline Protestants (e.g., Presbyterians, Episcopalians, etc.), Black Protestants (e.g., National Baptist Convention, National Missionary Baptist Convention, etc.), conservative Protestants (e.g., Church of Christ, Pentecostals, etc.), and "other" Protestants (Lutherans, Methodists, etc.). Again, Catholic is the reference group. Theory and research predicts that conservative Protestants should have lower fertility than Catholics, but higher fertility than mainline Protestants or any of the other Protestant groups. The results for Model 3 support this assertion. Specifically, on average and net of all other predictors, mainline Protestants have significantly lower fertility than Catholics. To explain further, mainline Protestants have about $\left(\mathrm{e}^{.097}-1\right)^{*} 100=9.2 \%$ fewer children than Catholics. Importantly, the fertility of conservative, Black, and other Protestants was not significantly different than that of Catholics.

With respect to comparing across the religious groups, our results suggest that membership in the different religious groups had differential effects on fertility. Specifically, an F-test for class variable comparison showed that the coefficients for at least one of the religious groups differed from the others $F[6,35896]=20.58, p<0.001$. Subsequent analyses revealed the differences to be mainly associated with the fertility of mainline Protestants. Over the entire time-period the fertility of mainline Protestants was about 1.85 children, while the fertility of conservative Protestants was significantly higher at about 2.03 children. The fertility of Black Protestants was also significantly higher than that of mainline or conservative Protestants at about 2.38 children. Thus, the results show that the fertility of conservative Protestants was significantly higher than that of mainline Protestants, but significantly lower than that of Catholics or Black Protestants.

The results presented so far are not unique and coincide with many other studies of religion and fertility. However, one area that is largely understudied is the trends in fertility of each religious group over time. According to previous research, conservative Protestants have higher fertility than other groups and that this is what is driving their increasing numbers [6,36,37]. This suggests that fertility 
rates by religious group should show conservative Protestant fertility to be moving away from that of mainline and other Protestant sects.

In order to test the hypothesis that in the last few decades the fertility rates of conservative Protestants have moved away from that of mainline Protestants and Catholics, it is necessary to include interactions between the key independent variables representing religious denomination and some function of time. The most general form of interaction would treat year as a class variable. Since this approach would involve estimating a large number of parameters, it would have relatively low power. Consequently, it is desirable to use some simple function of time in the interaction term. Since we are interested in gradual shifts, the most obvious possibility is a linear trend term increasing from 0 in 1984 to 24 in 2008. Interactions involving a trend term imply a steady divergence or convergence of groups over the whole period. In reality, change might take more complex forms-for example, the difference between groups might grow for a period of time, but then remain constant. However, the linear trend model provides a useful analytic starting point.

Estimates from a model including interactions with a linear trend are shown in the first and second columns of Table 3. The main effects are shown in the second column, while the interactions are shown in the third column. Our theoretical argument implies that the interactions between religious denomination and trend will be non-zero; that is, the fertility of conservative Protestants is growing relative to Catholics. In contrast to this expectation, the interaction with conservative Protestant is negative and not significant $(B=-0.003, p>0.05)$. A non-significant coefficient means that the trends in fertility rates for Catholics and conservative Protestants are moving in parallel. Said another way, over time, the gap between Catholics and conservative Protestants has remained the same. However, the gap between Catholics and those with other religious affiliations and those with no religious affiliation is growing larger $(\mathrm{B}=-0.007, \mathrm{p}<0.05$ and $\mathrm{B}=-0.005, \mathrm{p}<0.05$, respectively). This means that, the negative effects of no religion and other religion on fertility are growing stronger over time; said another way and relative to Catholics, those with no religion and other religions are having fewer children over time. The interactions involving the other religious dummy variables were non-significant. That is, although these variables may affect fertility, there is no indication that the effects have grown or declined over time.

Table 3. Negative Binomial Models Predicting Self-Reported Fertility over Time.

\begin{tabular}{lcc}
\hline & Model 4 & \\
$I V$ & Main Effect & Trend \\
\hline Intercept & $-4.223^{* * *}(0.356)$ & \\
Trend & $0.131^{* * *}(0.018)$ & \\
Cohort & & \\
Pre-New Dealers (before 1909) & $0.961 * *(0.171)$ & $-0.053^{* *}(0.020)$ \\
New Dealers (1909-21) & $0.659(0.354)$ & $-0.034 *(0.017)$ \\
World War II (1922-29) & $0.777 *(0.353)$ & $-0.035^{*}(0.017)$ \\
Cold Warriors (1930-45) & $1.066^{* *}(0.350)$ & $-.050^{* *}(0.017)$ \\
Early Boomers (1946-54) & $1.326^{* * *}(0.346)$ & $-0.066^{* * *}(0.017)$ \\
Late Boomers (1955-65) & $1.347 * * *(0.065)$ & $-0.054^{* * *}(0.017)$ \\
Generation X (1966-77) & $0.695^{*}(0.344)$ & $-0.011(0.017)$ \\
Generation Y (1978+) & ---- & ---- \\
\hline
\end{tabular}


Table 3. Cont.

\begin{tabular}{llc}
\hline Age & $0.150^{* * *}(0.006)$ & $-0.004^{* * *}(0.000)$ \\
Age*Age & $-0.001^{* * *}(0.000)$ & $0.000^{* * *}(0.000)$ \\
Married & $0.338^{* * *}(0.010)$ & \\
Female & $0.149^{* * *}(0.009)$ & \\
Education & $-0.054^{* * *}(0.002)$ & \\
Income (divided by 10,000) & $-0.003(0.002)$ & \\
Black & $0.276^{* * *}(0.018)$ & \\
Rural & $0.085^{* * *}(0.013)$ & \\
South & $-0.045^{* * *}(0.010)$ & $-0.007 *(0.003)$ \\
Religious Service Attendance & $0.015^{* * *}(0.002)$ & $-0.005 *(0.002)$ \\
& & $-0.002(0.002)$ \\
Other Religion & $-0.091^{*}(0.046)$ & $-0.003(0.003)$ \\
No Religion & $-0.078^{*}(0.038)$ & $-0.001(0.002)$ \\
Mainline Protestant & $-0.077^{* * *}(0.024)$ & $0.075(0.005)$ \\
Conservative Protestant & $0.009(0.023)$ & ---- \\
Black Protestant & $-0.023(0.033)$ & 38439.4 \\
Other Protestant & $0.001(0.044)$ & 33,587 \\
Catholic & ---- & \\
Deviance & & $4177.4 * * *(55)$ \\
LR $\chi^{2}(\Delta$ from null model $)$ & & \\
N & & \\
\hline
\end{tabular}

Note: $* \mathrm{p}<.05, * * \mathrm{p}<.01, * * * \mathrm{p}<.001$. Standard errors are in parentheses. Coefficients were not transformed by exponentiation for presentation. LR $\chi^{2}=$ deviance $_{\text {null }}-$ deviance $_{\text {fitted, }}$, with the number of parameters for the significance test in parentheses.

The interactions involving age and several of the cohort categories were also statistically significant. The results for age are more complicated and suggest that the inverted $U$ shape seen in Model 3 is "flattening out" over time. That is, in later years, an additional year of age is predicting fewer children than it did in the early period. The results from the Cohort variables echo this conclusion, as people in the later generations are having fewer children than those from the older generations.

\section{Discussion and Conclusions}

In general, the results presented in this paper confirm many of the findings available in the current literature. For example, we found that marriage increases fertility, as does being black and living in rural areas. On the other hand, additional years of schooling and higher incomes reduce the fertility of respondents in our sample. Importantly, we also found that those who attend religious services more regularly have higher fertility than those who do not attend services as often. This effect, although slightly attenuated, holds true even when religious denomination is controlled for.

The results of our cross-sectional analysis also confirm work that suggests Protestants have fewer children than Catholics. Traditionally, this gap has been attributed to the relatively stronger position on 
artificial birth control taken by the leadership of the Catholic Church compared to the stance held by the leaders of the various Protestant sects. We also found that Catholics have higher fertility than those who claim "other" religious affiliations and those who claim to have no religious affiliation. This, too, confirms previous research in the area of fertility and religion.

What is unique about our study is the focus on the fertility of the various Protestant sub-denominations. Thanks to work by [9] we were able to separate out the individual Protestant traditions and compare their fertility both to each other and to Catholics. Due to the ideology of some of the more fundamental Protestant sects, particularly conservative Protestants, which closely mirrors the Catholics' views on birth control, we expected that the fertility of conservative Protestants would be significantly higher than that of mainline Protestants and would even rival the fertility of Catholics. That is exactly what we found. When Protestants were separated into four categories (mainline, conservative, Black Protestants, and "other" Protestants) we found that only mainline Protestants reported significantly fewer children than did Catholics, controlling for a host of religious and demographic factors. This suggests that Protestants should not be considered one large homogeneous group. While our results underscored this point with regards to fertility, it is likely that the assumption that Protestants are a homogeneous group will not hold for a number of other outcome measures. For example, it is possible that topics fundamental to the study of religion in society such as religious participation and giving would benefit from studying them in light of the individual Protestant sects.

It is also possible that Catholics are not a homogeneous group. Westoff and Marshall ([38], p. 441) found that Hispanics have higher fertility than other ethnic groups and are more likely to be Catholic. This suggests that within the Catholic religion there may be a difference in fertility along ethnic lines. We leave this topic for future research. Another interesting avenue for future research would be to decompose the "conservative" Protestant group into its various components. That is, using the work of Blanchard et al. [39] as a guide, one could examine the fertility of evangelicals, fundamentalists, and Pentecostals separately. It is possible that these groups would show markedly different rates of fertility. As the within-conservative Protestant differences were not the focus of this paper, we also leave that for future research.

In addition to treating Protestants as a heterogeneous group, we also looked at the fertility trends of the various religious denominations over time. For the last few decades, researchers have documented a steady growth in the number of people claiming to be members of religious groups that we would classify as "conservative" Protestant. A number of scholars have attributed this growth to the greater fertility of the people in these groups along with (although to a much smaller degree) conversion and outreach by pastors and laypeople designed to increase membership numbers in specific churches. This argument suggests that the fertility of Protestants should be converging with (growing towards) that of Catholics and that the fertility of conservative Protestants in particular should be diverging (growing away) from that of Catholics.

In general, convergence/divergence implies two possible scenarios: First, the fertility of the specific groups are moving towards each other or away from each other at equal rates over time; that is, one group is having more/less children, while the other is having less/more children. Second, the fertility rates of one group are moving toward the other group, while the rates of the other group remain constant. Third, if two groups are becoming similar over time, then the rates of one group could exhibit a steeper slope than the rates of another group. That is, for example, the rates of Catholics may exhibit 
slope $X$, while the rates of conservative Protestants may exhibit a steeper slope, $2 X$. Thus, the fertility rates of conservative Protestants are "catching up" to the fertility rates of Catholics. It is these ideas that we tested with our trend analyses.

Although not presented in Table 3, we found no evidence for the converging of the fertility of Catholics and the fertility of Protestants. In fact, over time, there was a significant and negative interaction between a dummy variable for Protestant and our linear trend term. This means that the number of children reported by Protestants is growing smaller over time, relative to Catholics. Hence, we found a divergence and not a convergence in our results. As we cautioned above, however, it is probably a mistake to treat Protestants as one large homogeneous group. When Protestants are separated into their respective components and reentered into the model, the effect of time disappears. We found no significant trends in the fertility of mainline, conservative, Black Protestants, or other Protestants relative to Catholics. This means that our second proposition, that the fertility of conservative Protestants is surpassing that of Catholics and growing away from them, was not supported either. It seems as though the fertility rates of the various groups have not changed much over time. The exceptions to this were the fertility of those who claimed "other" religions and those who claimed "no religion." Over time, they both had significantly fewer children, on average, than Catholics.

One of the key implications of these findings is that conservative Protestants are a growing political force in American politics, not only because of the resonance of their movement's message but because of their high fertility rates. The prominence of the "religious right" in the contemporary conservative movement is one reason for its increased political and cultural power. Future research should explore the political implications of conservative Protestant fertility more directly. For example, are children born to conservative Protestant parents more likely to embrace conservative political identifications, vote for conservative candidates, and participate in elections? Additionally, are conservative Protestants' political orientations stable over time, or are there significant age, period, or cohort effects within this group? Conservative Protestant cohorts represent a particularly fruitful avenue for future study. Specifically, one key issue is whether higher fertility rates are translating into greater cohort sizes or, conversely, are a large number of children born to conservatives "leaving the flock." Moreover, it would be interesting to examine the political orientations of conservative Protestant cohorts and whether or not cohort size engenders greater political unity or diversity. Altogether, there is no doubt that conservative Protestants are a major political force in the U.S., however, their relatively high fertility may well ensure that they remain powerful for years to come.

In sum, this paper asked two fairly straightforward questions: 1) Are there differences in the fertility of the Protestant sub-denominations (particularly that of conservative Protestants)? And, 2) Does the growth in the number of conservative Protestants in the United States mean that the gap between Protestant and Catholic fertility is shrinking over time? Our findings suggest that there are indeed differences in fertility among the individual Protestant sects, but that those differences are not growing (or shrinking) over time. Additionally, the gap between Catholics and Protestants is not getting smaller and, especially among mainline Protestants, is getting larger. 


\section{References}

1. McQuillan, K. When Does Religion Influence Fertility? Popul. Dev. Rev. 2004, 30, 25-56.

2. Goldscheider, C. Population, Modernization, and Social Structure; Little, Brown, \& Co.: Boston, MA, USA, 1971.

3. Mosher, W.D.; Williams, L.B.; Johnson, D.P. Religion and Fertility in the United States: New Patterns. Demography 1992, 29, 199-214.

4. Williams, L.B.; Zimmer, B.G. The Changing Influence of Religion on U.S. Fertility: Evidence from Rhode Island. Demography 1990, 27, 475-481.

5. Mosher, W.D.; Hendershot, G.E. Religion and Fertility: A Replication. Demography 1984, 21, 185-191.

6. Marcum, J.P. Explaining Fertility Differences among U.S. Protestants. Soc. Forces 1981, 60, 532-543.

7. Westoff, C.F.; Jones, E.F. The End of "Catholic" Fertility. Demography 1979, 16, 209-217.

8. Woodberry, R.D.; Smith, C.S. Fundamentalism et al.: Conservative Protestants in America. Annu. Rev. Sociol. 1998, 24, 25-56.

9. Steensland, B.; Park, J.Z.; Regnerus, M.D.; Robinson, L.D.; Wilcox, W.B.; Woodberry, R.D. The Measure of American Religion: Toward Improving the State of the Art. Soc. Forces 2000, 79, 291-318.

10. Bader, C.D.; Mencken, F.C.; Froese, P. American Piety 2005: Content and Methods of the Baylor Religion Survey. J. Sci. Stud. Relig. 2007, 46, 447-463.

11. Hout, M.; Fischer, C.S. Why More Americans Have No Religious Preference: Politics and Generations. Am. Sociol. Rev. 2002, 67, 165-190.

12. Regnerus, M.D.; Smith, C. Selective Deprivatization Among American Religious Traditions: The Reversal of the Great Reversal. Soc. Forces 1998, 76, 1347-1372.

13. Pierce, L. Religion and the timing of first births in the United States. In Religion, Families, and Health; Ellison, C.G., Hummer, R.A., Eds.; Rutgers: Piscataway, NJ, USA, 2010; pp. 19-39.

14. Ryder, N.B.; Westoff, C.F. Reproduction in the United States, 1965; Princeton University Press: Princeton, NY, USA, 1971.

15. Whelpton, P.K.; Compbell, A.A.; Patterson, J.E. Fertility and Family Planning in the United States; Princeton University Press: Princeton, NY, USA, 1966.

16. DellaPergola, S. Patterns of American Jewish Fertility. Demography 1980, 17, 261-273.

17. Lenski, G. The Religious Factor: A Sociological Study of Religion's Impact on Politics, Economics and Family Life; Doubleday \& Co: Garden City, NY, USA, 1961.

18. Greeley, A. The Catholic Revolution: New Wine, Old Wineskins, and the Second Vatican Council; University of California Press: Los Angeles, CA, USA, 2004.

19. Bartkowski, J.P.; Xu, X.; Levin, M.L. Religion and child development: Evidence from the Early Childhood Longitudinal Study. Soc. Sci. Res. 2008, 37, 18-36.

20. Mahoney, A.; Pargament, K.I.; Murray-Swank, A.; Murray-Swank, N. Religion and sanctification of family relationships. Rev. Relig. Res. 2003, 44, 220-236.

21. Hempel, L.M.; Bartkowski, J.P. Scripture, sin and salvation: Theological conservatism reconsidered. Soc. Forces 2008, 86, 1647-1674. 
22. Bean, L.L.; Mineau, G.; Anderton, D. Residence and Religious Affects on Declining Family Size: An Historical Analysis of the Utah Population. Rev. Relig. Res. 1983, 25, 91-101.

23. Mosher, W.D.; Goldscheider, C. Contraceptive Patterns of Religious and Racial Groups in the United States, 1955-76: Convergence and Distinctiveness. Stud. Family Plan. 1984, 15, 101-111.

24. Goldscheider, C.; Mosher, W.D. Religious Affiliation and Contraceptive Usage: Changing American Patterns, 1955-82. Stud. Family Plan. 1988, 19, 48-57.

25. Greeley, A. Religion in the Year 2000; Sheed and Ward: New York, NY, USA, 1969.

26. Morrison, Emory. Conservative Churches and Fertility Innovation: A Cultural-Ecological Approach to the Second Demographic Transition among Nonblacks in the United States. J. Sci. Stud. Relig. 2009, 48, 103-120.

27. Hout, M.; Greeley, A. The Truth about Conservative Christians: What They Think and What They Believe; The University of Chicago Press: Chicago, IL, USA, 2003.

28. Kelley, D. Why Conservative Churches Are Growing; Harper and Row: New York, NY, USA, 1972.

29. Iannaccone, L.R. Why Strict Churches Are Strong. Am. J. Sociol. 1994, 99, 1180-1211.

30. Hammond, P.E. The Curious Path of Conservative Protestantism. Ann. Am. Acad. Polit. Soc. Sci. 1985, 480, 53-62.

31. Emerson, M.O.; Hartman, D. The Rise of Religious Fundamentalism. Annu. Rev. Sociol. 2006, 32, 127-144.

32. Shibley, M. Contemporary Evangelicals: Born-again and World Affirming. Ann. Am. Acad. Polit. Soc. Sci. 1998, 558, 67-87.

33. Davis, J.A.; Smith, T.W.; Marsden, P.V. General Social Surveys, 1972-2008. Roper Center for Public Opinion Research, University of Connecticut/Ann Arbor, MI, USA, 2008.

34. Tuch, S.A. Economic Segmentation and Racial Attitudes. Sociol. Q. 1987, 28, 513-522.

35. Tuch, S.A. Urbanism, Region, and Tolerance Revisited: The Case of Racial Prejudice. Am. Sociol. Rev. 1987, 52, 504-510.

36. Hout, M.; Greeley, A.; Wilde, M.J. The Demographic Imperative in Religious Change in the United States. Am. J. Sociol. 2001, 107, 468-500.

37. Thomas, J.N.; Olson, D.V.A. Testing the Strictness Thesis and Competing Theories of Congregational Growth. J. Sci. Stud. Relig. 2010, 49, 619-639.

38. Westoff, C.F.; Marshall, E.A. Hispanic fertility, religion and religiousness in the U.S. Pop. Res. Policy Rev. 2010, 29, 441-452.

39. Blanchard, T.C.; Bartkowski, J.P.; Matthews, T.L.; Kerley, K.R. Faith, morality and mortality: The ecological impact of religion on population health. Soc. Forces 2008, 86, 1-30.

(C) 2011 by the authors; licensee MDPI, Basel, Switzerland. This article is an open access article distributed under the terms and conditions of the Creative Commons Attribution license (http://creativecommons.org/licenses/by/3.0/). 